\title{
The Effect of Internal Control and Compliance with Accounting Rules on the Quality of Financial Statements at PT. Bank of North Sumatra Medan
}

\author{
Hasbiana Dalimunthe ${ }^{1}$, Aditya Amanda Pane ${ }^{2}$ \\ ${ }^{1,2}$ Universitas Medan Area, Indonesia \\ hasbianadalimunthe@staff.uma.ac.id,adityaamanda@staff.uma.ac.id
}

\begin{abstract}
This study aims to examine the effect of internal control and compliance with accounting rules on the quality of financial reports at PT Bank Sumatera Utara (North Sumatra). This research uses associative method. The population in this study were three divisions in Bank SUMUT, namely the Accounting and Tax Division, the General Division and the Operations Division. The sample used in this study were 35 respondents. The data analysis technique in this research is data quality test which includes validity and reliability tests, classic assumption test which includes normality test, multicollinearity test, heteroscedasticity test, and hypothesis test which includes $t$ test, determination test $(R 2)$ and multiple linear regression test.
\end{abstract}

Keywords

internal contrd; compliance with accounting rules, report quality finance

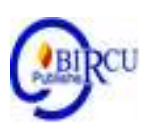

\section{Introduction}

The survival of a company can be achieved if the company can take advantage of market opportunities and opportunities and is able to compete, so that the goal of obtaining increased profits every year can be achieved. Assessment of the performance of a company can be seen from the company's financial statements which show the results of the company's accounting activities in a certain period. In agency theory, the higher the quality of the financial statements, the information gap between company stakeholders can be minimized (Jansen and Meckling, 1976: 305). Financial reports describe the financial condition and results of operations of the company at a certain time or for a certain period (Harahap, 2010).

The presentation of financial statements is regulated in PSAK No. 1, which states that "The financial statements are a structured presentation of the financial position and financial performance of an entity". Financial reports can be used to assess the achievements of the company in the past, present and plans for the future. The quality of financial reports must have characteristics, namely relevant, reliable, comparable and understandable to users of financial statements.

According to RI Law Number 10 of 1998Regarding banking, the definition of a bank is "a business entity that collects funds from the public in the form of deposits. Apart from that, it also distributes to the public in the form of credit and / or other forms in order to increase companies engaged in the financial sector.Management professionalism is needed to increase the productivity of its operational activities. To avoid threats that can interfere with banking objectives, internal controls are required. Effective internal control can be used to protect all banking assets, increase compliance with applicable laws and regulations, and protect assets owned by banks from all human resource fraud. In the credit phenomenon, one way to maintain credit security is the need for internal control, so that the risk of bad credit can be avoided. 
The preparation of financial statements must comply with accounting rules, which are guided by the rules issued by the Indonesian Institute of Accountants (IAI). Adherence to accounting rules can create transparency in financial reports, as well as conformity to procedures and policies in asset management.

\section{Review of Literatures}

\subsection{Definition of Financial Report Quality}

Financial statements are information that describes the financial condition of an entity. The manager is the party most responsible for the quality of financial reports. The financial report contains the company's financial position, performance, reports of incoming and outgoing funds and includes a company's capital report. The quality of financial reports is a structured report regarding the statement of financial position and transactions carried out and accounted for by an entityreporting (Fanani,2008). To meet user needs, financial reporting must have criteria, namely relevant, reliable, comparable, understandable and timely (Saidin, 2007).

Financial statements are basically a source of information for investors as one of the basic considerations in making capital market investment decisions and also as a means of management responsibility for the resources entrusted to them. This shows that financial reports are an important medium for conveying corporate disclosure by company management and are an important source of information in making investors' decisions. So that financial reports that have been audited by a public accountant can be a useful basis for decision making, one way that can be taken is to create criteria for the need for certain disclosures that can cover all public companies. (Subiyantoro in Prayogo et al, 2021).

Bank Indonesia in Lubis (2019) defines financial inclusion as all efforts aimed at eliminating all forms of price and non-price barriers to public access in utilizing financial services. The Otoritas Jasa Keuangan (2016) defines financial inclusion as the availability of access to various financial institutions, products and services in accordance with the needs and abilities of the community in order to improve public welfare. OECD, Organization for Economics Co-operation Development (2016) has developed questions on the questionnaire that can be used to measure the level of financial inclusion.

Financial performance is a measuring instrument to know the process of implementing the company's financial resources. It sees how much management of the company succeeds, and provides benefits to the community. Sharia banking is contained in the Law of the Republic of Indonesia No.21 of 2008 article 5, in which the Financial Services Authority is assigned to supervise and supervise banks. (Ichsan et al, 2021).

\subsection{Financial report Quality Indicators}

Indicators of the quality of financial reports according to Sudiarianti (2015) include:

1. Relevant

Relevant financial reports are financial statements that can provide information that can influence users' decisions to evaluate past and present events and serve as guidelines for predicting future events.

2. Reliability

The financial information presented must be of reliable quality which means that the information provided is not misleading, is presented honestly and can be verified.

3. Can be compared

Financial information is more useful if it can be compared to company financial reports between periods and financial reports from one company to another. 


\section{Can be understood}

Financial reports must be understandable by users and expressed in forms and terms that are tailored to the capabilities of users of financial statements.

According to KRSubramanyam and Jhon J. Wild (2014; 90), "the quality of accounting information desired, namely:

1. Relevant, has implications for the timely characteristics of the presentation of financial statements.

2. Reliable, information must be verifiable, reliable, presented honestly that reflects reality and is neutral.

3. Comparability and consistency are secondary qualities of accounting information. Comparability means information is measured in the same way or by generally accepted standards. Consistency means for the same transactions over time using the same methods.

If information is free from misleading notions, material errors, presented honestly and fairly and reliably, then the information can be said to be of high quality (Herawati, 2014).

\subsection{Definition of Internal Control}

Control ensures that there are directions and policies from management that must be carried out properly. Internal control is needed in a company so that the company's operational activities can run well and achieve its goals and the business continuity of a company. According to Boynton et al (2002) "internal control is an activity carried out by the board of directors, management and other personnel to provide adequate assurance regarding the achievement of objectives, namely: reliability of financial reporting, compliance with applicable laws, efficiency and effectiveness of operations to maintain assets. company".

According to Mokoginta (2017) "in a company organization, both for profit and nonprofit organizations, internal control is essential because operational and performance activities require a special policy that is able to accommodate and provide specific limits and provisions in each of its activities".

\subsection{Internal Control Indicators}

According to the Committee of Sponsoring Organizations of the Tradeway or COSO (Baidaie, 2005) which includes internal control indicators including:

1. Control environment

The awareness of the assignment of all employees is affected by the control environment. The control environment is the basis of all components of control because it involves discipline and structure.

2. Risk Assessment

Risk assessment includes a process to identify, analyze and assess the risks that will occur in the presentation of financial statements.

3. Control Activities

Control activities apply the policies and procedures that must be established to assure management that all directions have been properly implemented. Control activities are implemented at all levels of the organization, data processing, functions and other control components. 
4. Information and communication

Information and communication are two important elements to assist management in carrying out its responsibilities. Management uses information systems to convey information in a timely and effective manner. This concerns the accounting system which consists of methods for recording, identifying, analyzing, classifying and reporting transactions that occur in the accountability of company assets and debts.

5. Evaluation Process

Evaluation aims to assess the implementation of internal control and make improvements if it is deemed necessary.

\subsection{Adherence to Accounting Rules}

Adherence to accounting rules is a requirement that companies must obey in terms of making financial reports in accordance with accounting standards so that the presentation of financial statements is fair and reliable. According to the Government Regulation of the Republic of Indonesia Number 24 (2005), financial accounting standards are used as rules in every accounting activity. In seeing the suitability of the entity's asset management procedures, it is necessary to comply with accounting rules with predefined accounting standards.

\subsection{Indicators of Compliance with Accounting Rules}

According to Rahmawati and Idjang (2012) "accounting rules are made as a basis in preparation of financial reports ". Meanwhile, according to (Rizky, 2016) an agency's accounting activities must be carried out in accordance with its accounting rules.

Indicators of adherence to accounting rules according to Thoyibatun (2009), include:

1. Disclosure requirements

Disclosure requirements are very important because every company must present financial statements in accordance with the applicable accounting standards in presenting accounting information.

2. Presenting useful information for the public interest.

As a form of accountability for its duties, the company must present a financial report on the company's performance that is beneficial to stakeholders.

3. Objective

In the presentation of financial statements the objective principles must be applied. Financial statement information is presented fairly, honestly and fairly addressed to users without depending on the needs of certain parties.

4. Meets precautionary requirements

In carrying out its duties to prepare financial reports, care must be taken so that the information on financial statements is reliable, relevant, and understandable for users.

5. Meet the concept of presentation consistency

Accounting treatment can be applied in the same method but can also be applied in a different method if the method can be better than before.

Investors and management are the users of financial statements with the aim of being able to make decisions. Because of the importance of this information, financial reports should be reliable. Therefore, a rule is needed to maintain the reliability of this information and avoid actions that can harm the company or organization (Lilik, 2016). Wolk and Tearney (1997) in Wilopo (2006) explain that the occurrence of fraud in the company is caused by failure to prepare financial statements due to non-compliance with accounting rules. 


\section{Research Methods}

This type of research is associative research. The sample in this study were 35 respondents who played a role in the preparation of financial statements at the Bank of North Sumatra. The data source used in this study is primary data using a questionnaire. The type of data used in this research is quantitative data. The data analysis technique in this study used multiple linear regression. The data quality was then tested by means of validity and reliability tests. The classical assumption test uses the normality test, multicollinearity test, and heteroscedasticity test.

\section{Result and Discussion}

The validity of an indicator if $r$ count $>r$ table. To determine the $r$ table seen from the formula (n-2) where $\mathrm{n}$ is the number of questionnaires distributed, it is obtained 35-2=33 with a significant level of $5 \%(0.05 \%)=0.2826$. The validity test of this research can be displayed in table 1 below as follows:

To test the validity of the internal control variable (X1), it will be explained in table 1 below, namely:

Table 1.The Results of the Validity Test for Internal Control Variables

\begin{tabular}{|c|c|c|c|}
\hline No. & Kcorrelation & $\mathbf{R}$ table & Status \\
\hline 1. & 0.413 & 0.2826 & Valid \\
\hline 2. & 0.469 & 0.2826 & Valid \\
\hline 3. & 0.338 & 0.2826 & Valid \\
\hline 4. & 0.373 & 0.2826 & Valid \\
\hline 5. & 0.409 & 0.2826 & Valid \\
\hline 6. & 0.415 & 0.2826 & Valid \\
\hline 7. & 0.414 & 0.2826 & Valid \\
\hline 8. & 0.554 & 0.2826 & Valid \\
\hline 9. & 0.488 & 0.2826 & Valid \\
\hline 10. & 0.716 & 0.2826 & Valid \\
\hline 11. & 0.707 & 0.2826 & Valid \\
\hline 12. & 0.868 & 0.2826 & Valid \\
\hline 13. & 0.628 & 0.2826 & Valid \\
\hline 14. & 0.778 & 0.2826 & Valid \\
\hline 15. & 0.595 & 0.2826 & \\
\hline
\end{tabular}

Based on table 1 above, it is explained that all statement items / questionnaires for internal control variables are valid. This is evidenced by the correlation coefficient value greater than the $\mathrm{R}$ table value or the correlation coefficient value greater than 0.05 . To test the validity of the accounting rule compliance variable (X2), it will be explained in Table 2 below, namely: 
Table 2.Validity Test Results for Obedience to Accounting Rules Variables

\begin{tabular}{|c|c|c|c|}
\hline No. & Kcorrelation & $\mathbf{R}$ table & Status \\
\hline 1. & 0.467 & 0.2826 & Valid \\
\hline 2. & 0.867 & 0.2826 & Valid \\
\hline 3. & 0.648 & 0.2826 & Valid \\
\hline 4. & 0.689 & 0.2826 & Valid \\
\hline 5. & 0.703 & 0.2826 & Valid \\
\hline 6. & 0.689 & 0.2826 & Valid \\
\hline 7. & 0.685 & 0.2826 & Valid \\
\hline 8. & 0.748 & 0.2826 & Valid \\
\hline 9. & 0.900 & 0.2826 & Valid \\
\hline 10. & 0.752 & 0.2826 & Valid \\
\hline 11. & 0.626 & 0.2826 & Valid \\
\hline 12. & 0.745 & 0.2826 & Valid \\
\hline 13. & 0.690 & 0.2826 & Valid \\
\hline 14. & 0.748 & 0.2826 & Valid \\
\hline 15. & 0.758 & 0.2826 & \\
\hline
\end{tabular}

Based on table 2 above, it is explained that all statement items / questionnaire variables obedience to accounting rules are valid. This is evidenced by the correlation coefficient value greater than the $\mathrm{R}$ table value or the correlation coefficient value greater than 0.05 . To test the validity of the variable quality of financial statements (Y), it will be explained in table 3 below, namely:

Table 3. Results Test the Validity of the Quality Variable Financial Statements

\begin{tabular}{|c|c|c|c|}
\hline No. & Kcorrelation & $\mathbf{R}$ table & Status \\
\hline 1. & 0.481 & 0.2826 & Valid \\
\hline 2. & 0.909 & 0.2826 & Valid \\
\hline 3. & 0.909 & 0.2826 & Valid \\
\hline 4. & 0.896 & 0.2826 & Valid \\
\hline 5. & 0.613 & 0.2826 & Valid \\
\hline 6. & 0.741 & 0.2826 & Valid \\
\hline 7. & 0.746 & 0.2826 & Valid \\
\hline 8. & 0.916 & 0.2826 & Valid \\
\hline 9. & 0.751 & 0.2826 & Valid \\
\hline 10. & 0.710 & 0.2826 & Valid \\
\hline 11. & 0.886 & 0.2826 & Valid \\
\hline 12. & 0.916 & 0.2826 & Valid \\
\hline 13. & 0.600 & 0.2826 & Valid \\
\hline 14. & 0.896 & 0.2826 & Valid \\
\hline 15. & 0.613 & 0.2826 & \\
\hline
\end{tabular}


Based on table 3 above, it is explained that all statement items / questionnaires for the quality variable of financial statements are valid. This is evidenced by the correlation coefficient value greater than the $\mathrm{R}$ table value or the correlation coefficient value greater than 0.05 . The reliability test in this study is as follows:

Table 4. Results Variable Reliability Test

\begin{tabular}{|c|l|l|c|c|}
\hline No. & \multicolumn{1}{|c|}{ Variable } & $\begin{array}{r}\text { Cronbach } \\
\text { Alpha }\end{array}$ & $\begin{array}{l}\text { Cutt } \\
\text { Off }\end{array}$ & Status \\
\hline 1. & PeInternal Control (X1) & 0.830 & $>0.60$ & Reliable \\
\hline 2. & Compliance with Accounting Rules & 0.931 & $>0.60$ & Reliable \\
\hline 3. & Financial Report Quality (Y) & 0.951 & $>0.60$ & Reliable \\
\hline
\end{tabular}

From table 4 above shows that the internal control variable (X1) has a reliable status with evidence of a Cronbach Alpha value of 0.830> 0.60. For the accounting rule obedience variable (X2) shows a reliable status with evidence of a Cronbach Alpha value of 0.931>0.60. For the variable quality of financial reports (Y) shows a reliable status with evidence of a Cronbach Alpha value of $0.951>0.60$.

In this study using the classical assumption test as follows:

\subsection{Normality Test}

Table 5. Normality Test Results

One-Sample Kolmogorov-Smirnov Test

\begin{tabular}{|c|c|c|}
\hline & & Unstandardized Residual \\
\hline $\begin{array}{l}\text { N } \\
\text { Normal } \\
\text { Parametersa, } \\
\text { b } \\
\text { Most Extreme } \\
\text { Differences } \\
\text { Kolmogorov-Sm }\end{array}$ & \begin{tabular}{l|} 
Mean \\
Std. Deviation \\
Absolute \\
Positive \\
Negative \\
nirnov Z
\end{tabular} & $\begin{array}{r}35 \\
, 0000000 \\
2,77171014 \\
, 104 \\
, 104 \\
-, 095 \\
, 617\end{array}$ \\
\hline Asymp. Sig. (2-t & tailed) & , 842 \\
\hline
\end{tabular}

Based on table 5 above, it can be concluded that the data is normally distributed, with evidence of a sig value of 0.842 which is greater than 0.05 .

\subsection{Multicollinearity Test}

Table 6. Results Multicollinearity Test

\section{Coefficientsa}

\begin{tabular}{|l|l|r|r|}
\hline \multirow{2}{*}{ Model } & Collinearity Statistics & \multicolumn{2}{|c|}{} \\
\cline { 2 - 3 } & Tolerance & VIF & 1,000 \\
\hline \multirow{3}{*}{1} & (Constant) & 1,000 & 1,000 \\
\hline & INTERNAL CONTROL & 1,000 & \\
\cline { 2 - 3 } & COMPLIANCE WITH & & \\
\hline
\end{tabular}

a. Dependent Variable: QUALITY OF FINANCIAL STATEMENTS

Table 6 above shows that the regression test does not have multicollinearity problems, this is evidenced by the tolerance value greater than 0.10 and the VIF value less than 10 . 


\subsection{Heteroscedasticity Test}

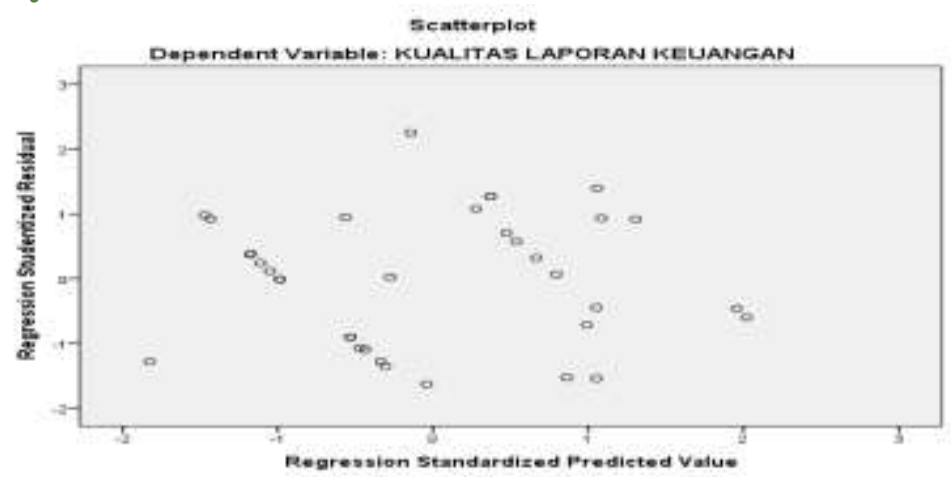

Figure 1. Heteroscedasticity Test Results

From Figure 1 above shows that there is no heteroscedasticity, this is evidenced by the randomly spreading points above or below zero on the $\mathrm{Y}$ axis.

\subsection{Multiple Linear Regression Test Results}

Table 7. Multiple Linear Regression Results

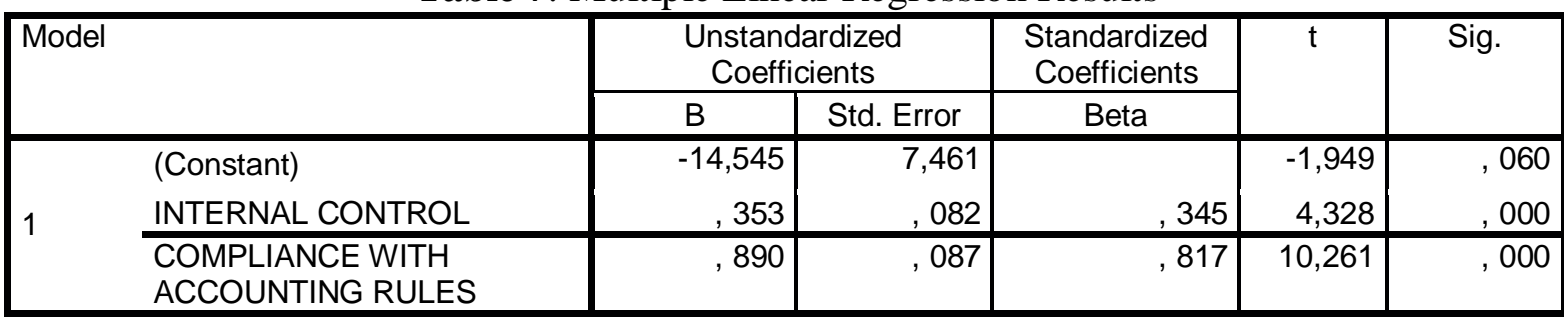

Based on the results of the multiple linear regression statistical test above, it can be explained in the following equation:

$$
\begin{array}{r}
\mathrm{Y}=\alpha+\mathrm{b} 1 \mathrm{X} 1+\mathrm{b} 2 \mathrm{X} 2+\mathrm{e} \\
\mathrm{Y}=\mathbf{1 4 , 5 4 5}+\mathbf{0 . 3 5 3} \mathrm{X} 1+\mathbf{0 . 8 9 0} \mathrm{X} 2+\mathrm{e}
\end{array}
$$

\subsection{Hypothesis Testing}

This is to determine whether or not the independent variable influences the variable dependent required $t$ test. The $t$ test of this research is described in the table below:

Table 8. ResultT test

\section{Coefficientsa}

\begin{tabular}{|l|l|l|l|}
\hline Model & S & & \\
\hline & & & \\
\hline \multirow{2}{*}{1} & (Constant) & $-1,949$ &, 060 \\
& $\begin{array}{l}\text { INTERNAL } \\
\text { CONTROL }\end{array}$ & 4,328 &, 000 \\
\hline & $\begin{array}{l}\text { RULES OF } \\
\text { ACCOUNTING }\end{array}$ & 10,261 &, 000 \\
\hline
\end{tabular}

a. Dependent Variable: Quality of Financial Statements

Based on table 8 above, the internal control variable (X1) is obtained t count $>t$ table $(4,328>2,039)$. For the accounting rule obedience variable $(X 2)$ is obtained $t$ count $>t$ table $(10,261>2,039)$. Then for the two independent variables it is significant, it shows $<0.05$. This 
shows that internal control has a partial effect on the quality of financial reports. This means that increasing internal control within the company can improve the quality of financial reports. Management periodically checks accounting records. Adherence to accounting rules partially affects the quality of financial reports. Disclosure requirements are very important because every company must present financial statements in accordance with the applicable accounting standards in presenting accounting information. If you experience difficulties in carrying out management duties, you must consistently use accounting standards.

\subsection{Determination Coefficient Test ( $R 2)$}

Table 9. The results of the determination coefficient test

Model Summary b

\begin{tabular}{l|r|r|r|r|}
\hline Model & $\mathrm{R}$ & $\mathrm{R}$ Square & $\begin{array}{c}\text { Adjusted R } \\
\text { Square }\end{array}$ & $\begin{array}{c}\text { Std. Error of the } \\
\text { Estimate }\end{array}$ \\
\hline 1 &, $893 a$ &, 797 &, 785 & 2,857 \\
\hline
\end{tabular}
a. Predictors: (Constant), COMPLIANCE WITH ACCOUNTING
RULES, INTERNAL CONTROL
b. Dependent Variable: QUALITY OF FINANCIAL STATEMENTS

Based on table 9 above shows the R Square value of 0.797 or $79.7 \%$. It can be concluded that the relationship between the qualities of financial statements can be explained by the internal control variables and the compliance with accounting rules of $79.7 \%$ and the remaining $20.3 \%$ is influenced by other factors not examined.

\section{Conclusion}

1. Internal control affects the quality of financial reports at PT. Bank SUMUT. This means that managers show independence from management in developing the implementation of internal control. PT. SUMUT Bank carries out internal control in accordance with established procedures and policies. If the internal controls implemented by PT. Bank SUMUT are going well, then the quality of the financial reports of PT. Bank SUMUT will also be good.

2. Adherence to accounting rules affects the quality of financial statements at PT. Bank SUMUT. This means that banks as agents of development in all business and business sectors must apply the principle of prudence (prudential banking). In carrying out its duties, management must consistently use accounting standards in accordance with existing guidelines. The higher the level of compliance with accounting rules implemented by PT. Bank SUMUT, the better the quality of the resulting financial reports.

\section{References}

Anna Arifah. (2017). Pengaruh Ketaatan Aturan Akuntansi, Kefektifan Pengendalian Internal, Kesesuaian Kompensasi, Keadilan Prosedural, Dan Komitmen Organisasi Terhadap Kecendrungan Kecurangan Akuntansi (Studi pada Perguruan Tinggi Negeri di Daerah Istimewa Yogyakarta).

Bank Indonesia. (1998) UU No.10 tahun 1998, Tentang Perubahan Terhadap UU No. 7 tahun 1992, Jakarta

Baidaie, M.Chatim. 2005. Corporate Governance dan Kebijakan Audit. Edisi Revisi. Yayasan Pendidikan Internal Audit, Institut Pendidikan dan Pelatihan Audit dan Manajemen, Jakarta.

Boynton, Johnson, Kell. (2002). Modern Auditing. Edisi Ketujuh.Jilid Satu.Erlangga: Jakarta. 
Fanani, Zaenal. (2008). Kualitas Pelaporan Keuangan: Faktor-Faktor Penentu dan Prosiding Simposium Nasional Akuntansi VIII

Harahap. Sofyan syafri. (2010). Analisis Kritis Atas Laporan Keuangan. Jakarta: Pt. Raja Grafindo Persada.

Tuti Herawati. (2014).Pengaruh Sistem Pengendalian Intern Terhadap Kualitas Laporan Keuangan (Survei Pada Organisasi Perangkat Daerah Pemda Cianjur), Junal Star-study \& Accounting Reaserch, Vol. XI, No. 1, 2014, 6

Ichsan, R. et al. (2021). Determinant of Sharia Bank's Financial Performance during the Covid19 Pandemic. Budapest International Research and Critics Institute-Journal (BIRCIJournal). P. 298-309

Ikatan Akuntansi Indonesia. Standar Akuntansi Keuangan.(2011). Jakarta: Penerbit Salemba Empat

Jansen, M., and Meckling, W.(1976). Theory of The Firm : Managerial Behavior, Agency Cost, and Ownership Structure. Journal Of Financial Economics, $3: 305-306$.

K.R.Subramanyam.,Jhon J.Wild.(2014).Analisis Laporan Keuangan.Jakarta: Penerbit Salemba Empat.

Lilik Lia Arista. (2016). Pengaruh Faktor-Faktor Internal Terhadap Kecenderungan Kecurangan Akuntansi Pada PT. Pegadaian Persero Surakarta. Jurnal Ekonomi Bisnis, Volume 6, Nomor 2, Bulan Juli Tahun 2015 Hal 115-122.

Lubis, A. et al. (2019). Antecedents Effect of Financial Inclusion for the People of North Sumatera. Budapest International Research and Critics Institute-Journal (BIRCIJournal). P. 401-408.

Novtania Mokoginta., Linda Lambey.,Winston Pontoh.(2017). Pengaruh Sistem Pengendalian Iinternal Dan Sistem Akuntansi Keuangan Daerah Terhadap Kualitas Laporan Keuangan Pemerintah. Jurnal Riset Akuntansi Going Concern 12(2), 2017, 874-89

Nuraini,Muslimin dan Kahar, Abdul.(2018).Pengaruh pengendalian internal dan ketaatan pada aturan akuntansi terhadap kualitas laporan keuangan (studi pada bendahara skpd sekabupaten buol.

Peraturan pemerintah RI Nomor 24 (2005), Standar akuntansi keuangan.

Prayogo, I. et al. (2021). Perceptions of Educators, Accounting Students and Accountants Public Accountant against Ethics of Financial Statement Preparation (Studies at University and KAP in Semarang). Budapest International Research and Critics InstituteJournal (BIRCI-Journal). P. 89-101.

Rahmawati, Ardiana Peni, dan Idjang Soetikno. (2012). Analisis Pengaruh Faktor Internal dan Moralitas Manajemen Terhadap Kecenderungan Kecurangan Akuntansi. Jurnal Publikasi. Universitas Diponegoro.

Rizky Ramaidha. (2016). Pengaruh Keefektifan Pengendalian Internal, Ketaatan Aturan Akuntansi, dan Kepuasan Kerja terhadap Kecurangan Akuntansi, Studi pada 17 SKPD di Kota Magelang: Universitas Yogyakarta.

Saidin, Saidatur Fauzi. (2007). Audit Committee Characteristics and Quality of Unaudited Financial Accounts. Diakses 10 Maret 2010.

Sudiarianti, Ni Made. 2015. Pengaruh Kompetensi Sumber Daya Manusia pada Penerapan Sistem Pengendalian Intern Pemerintah dan Standar Akuntansi Pemerintah Serta Implikasinya pada Kualitas Laporan Keuangan Pemerintah Daerah. Jurnal Riset Akuntansi. Program Pascasarjana Universitas Udayana Denpasar. Vol. 1 No. 1. Hal. 1-25.

Wilopo. (2006). Analisis Faktor-Faktor yang Berpengaruh Terhadap Kecenderungan Kecurangan Akuntansi: Studi Pada Perusahaan Pubik dan Badan Usaha Milik Negara di Indonesia. Simposium Nasional Akuntansi 9.

Siti Thoyibatun. (2009). Faktor-faktor yang Berpengaruh terhadap Perilaku Tidak Etis dan Kecenderungan Kecurangan Akuntansi Serta Akibatnya terhadap Kinerja Organisasi. Jurnal Ekonomi dan Keuangan volume 16 nomer 2:245-260 